\title{
A Message for “Going Green”Can We Make Our Planet Sustainable and Living one Forever?
}

Vish Kallimani*

Department of Computer and Information Sciences, Petronas University of Technology, Bandar Seri Iskandar, 31750 Tronoh, Perak, Malaysia

*Corresponding author: Kallimani V, Department of Computer and Information Sciences, Petronas University of Technology, Bandar Seri Iskandar, 31750 Tronoh, Perak, Malaysia, Tel: +605 368 7431; E-mail: Vish.kallimani@petronas.com.my

Received date: Dec 11, 2015, Accepted date: Dec 12, 2015, Published date: Dec 20, 2015

Copyright: (c) 2015 Kallimani V. This is an open-access article distributed under the terms of the Creative Commons Attribution License, which permits unrestricted use, distribution, and reproduction in any medium, provided the original author and source are credited.

\section{Global Warming}

This question is daunting in this century. Compared to the previous centuries this century the $\mathrm{CO}_{2}$ emissions have shot up exponentially due to industrializations and other inventions and practices. Global warming is the threat which is affecting the living planet. In the last century average global temperature rose by more than $10^{\circ} \mathrm{F}$ and some regions by $40^{\circ} \mathrm{F}$. The annual greenhouse gas emissions such as Carbon dioxide, Methane and Nitrous oxide increase the carbon footprint. These results are due to the man made mistakes i.e., the inventions without considering the planet's health and eco imbalance. The modern technologies, inventions, industries and daily practices as an individual are all added up into $\mathrm{CO}_{2}$ emissions, resulting which annually we are spewing about 40 Billion Tons/annum to the atmosphere. And this figure is increasing day by day. This is an alarming stage where every individual and nations have to work in reducing the threat.

Is it possible to reduce the Global warming? Certain extent yes, it is necessary for everyone to be educated, have a mindset, and do some practices. This book intended to discuss on the Global warming, Green Technologies, Greener practices[1,2].

The necessity of going green is critical and vital. Global warming is a threat to this planet, due to manmade inventions in modern technology. In order to reduce the greenhouse gases (40 Billion tons emitted annually), which causes global warming. It is evident that every individual on this planet must respect mother earth. It is high time for GREEN, Sustainable and Smart projects, education, ideations, research and innovations in professions, Pedagogy (School to universities), services and practices, and living to be put into practice.

A need to transform conventional cities (villages, Islands, Settlements) into smart and sustainable cities villages, Islands, Settlements) is essential around the world. As population grows, space, energy and vital resources would need to be designed, implemented, maintained and managed properly in order for citizens and all other beings to live a better life. India, the second most populous country in the world, currently taking the initiative towards developing its cities to smart cities, would be an exemplary step for all the other developing countries and the developed countries around it [3].

\section{References}

1. NASA Sciences (2014) NASA to Launch Carbon Observatory, Science News.

2. NRDC (2015) global warming.

3. Osborn L (1880) History of Changes in the Earth's Temperature. Weather and Science facts. 